\title{
Corporate Paint and Ancient Pharmaceutical Mixtures from Teotihuacan: the Teopancazco Neighborhood Center
}

\author{
Ma. Luisa Vázquez de Ágredos Pascual ${ }^{1 *}$, Linda R. Manzanilla ${ }^{2}$ \\ ${ }^{1}$ Art History Department, Universidad de Valencia, Avenue Blasco Ibáñez 28, 46010, Valencia, Spain \\ ${ }^{2}$ UNAM-México, El Colegio Nacional
}

\begin{abstract}
Received: November 28, 2016; Accepted: December 15, 2016; Published: December 22, 2016
*Corresponding author: Ma. Luisa Vázquez de Ágredos Pascual, Professor, Art History Department, Universidad de Valencia, Avenue Blasco Ibáñez 28, 46010, Valencia, Spain, Tel: (0034) 963864241, Fax: (0034) 963864496; E-mail: mavazdea@uv.es
\end{abstract}

\begin{abstract}
This work describes the whole range of body colors with medical properties found in different contexts in the multiethnic neighborhood center of Teopancazco, in the Classic Mesoamerican city of Teotihuacan (AD 200-550). This neighborhood center located in the southeastern part of the city had strong ties to the Gulf Coast of Mexico, particularly to Nautla in Veracruz. Our study suggests that the preparation and confection of body colors (i.e., pigments used for painting one's skin) was one of the specialized activities at Teopancazco, together with garment-making, basket manufacture, and pottery and mural painting. Another specialized activity was the practice of medicine. Both are closely related. A careful analysis of functional sectors in the Teopancazco compound, and the interdisciplinary perspective implemented by Linda R. Manzanilla and her team provided new information on medical practices in Teotihuacan, the most important city of Classic Mesoamerica. This research states that important activities provided by specialists based in neighborhood centers were medical interventions, childbirth assistance, and the preparation of medical prescriptions.
\end{abstract}

Keywords: Teotihuacan; Teopancazco; Body colors; Galena; Cinnabar; Jarosite

\section{Abbreviations}

cm: Centimeter; eV: Electrovolt; kV: Kilovolt; min: Minutes; mL: a Milliliter; mm: Millimeter; $n m$ : Nanometer; s: Second; $\mu \mathrm{L}$ : a Milliliter cubic; NO: Nitrogen monoxide; AD Christian Era; BC before the Christian Era

\section{Introduction}

During the Classic period (AD 150-600), the great city of Teotihuacan was the main urban development of Central Mexico; it was a ca. $20 \mathrm{~km}^{2}$ city, with an orthogonal urban grid (an uncommon characteristic in Mesoamerica), one of the largest preindustrial cities of the ancient world [1] [Figure 1]. The city may have been divided into four districts [2], these districts may have been the main administrative divisions articulating the diversity of the population. And from these districts probably emerged the participants of the co-rulership of the Teotihuacan state, one of the dimensions of its corporate organization [3].

In each district, different neighborhoods were located, which constituted the most dynamic social units of the Teotihuacan society. These neighborhoods had coordination centers, and were probably headed and managed by the intermediate elite, an entrepreneurial class who competed to bring to the city the most exotic and strange ornaments and garments for public display $[4,5]$. We have counted ca. 22 of these neighborhood centers in the city [6]. Numerous apartment compounds surrounded each neighborhood center.

Around the core, the ethnic enclaves [7] of people coming from Oaxaca (Tlailotlacan), Michoacán and Veracruz (Mezquititla and Xocotitla) were located, each one reproducing its original identity through distinctive funerary rituals, symbolic items (urns, stelae, figurines), and foreign goods. The Oaxaca Barrio and the three concentrations of Oaxaca people settled along the Western Avenue of Teotihuacan that Veronica Ortega, et al [8] has proposed may suggest that the Oaxaqueños were the most numerous foreign group in the metropolis.

The extensive excavations (1997-2015) of the Teopancazco neighborhood center (square S2E2 in Millon's map, located to the south of the Ciudadela) by Linda R. Manzanilla [9] and her team [Figure 2, 3], revealed a coordination center for a peripheral neighborhood in the southeastern sector of Teotihuacan, with

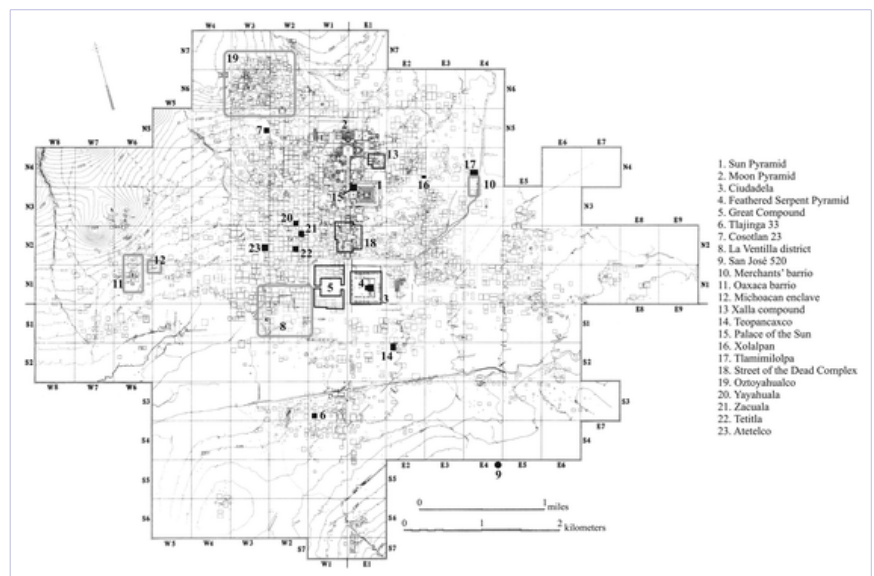

Figure 1: Millon's map (1973) 
strong ties to the Gulf Coast of Mexico. Large craft production sectors are found; and few traces of domestic activities are seen. This neighborhood has an important development between the Tlamimlolpa phase (AD 200-350) and the Xolalpan phase (AD 350-550).

For Teopancazco, the main craft activity was the manufacture of garments and headdresses [10] such as the one displayed in the main mural painting found at the site; other crafts evidence in this neighborhood center were the manufacture of nets, baskets, and the painting of pottery [10]. Important burials of adolescents at Teopancazco were accompanied by miniatures containing odorous resins, mixtures of pigments (such as cinnabar, jarosite, hematite, galena) with carbon. A similar presence was detected by Sigvald Linné (1934: 160-161) in the Xolalpan compound.

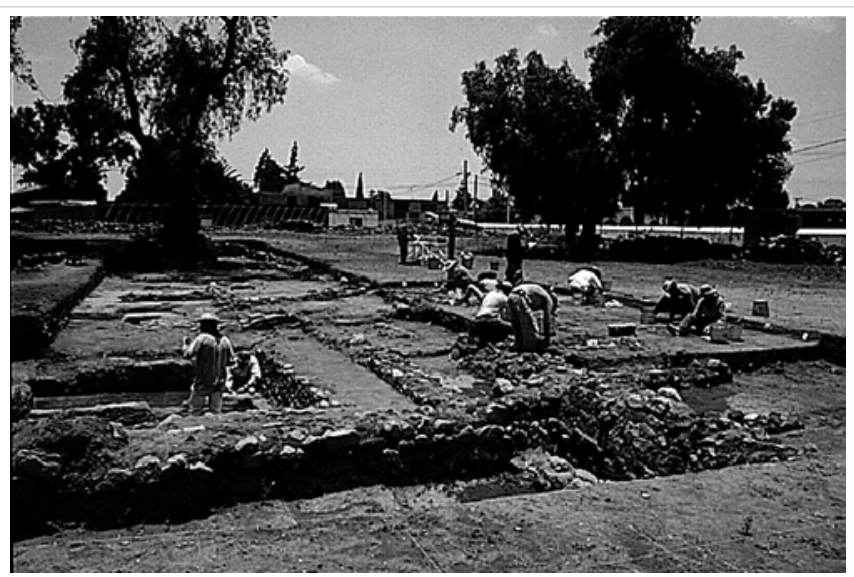

Figure 2: Excavation of the Metepec northeastern sector

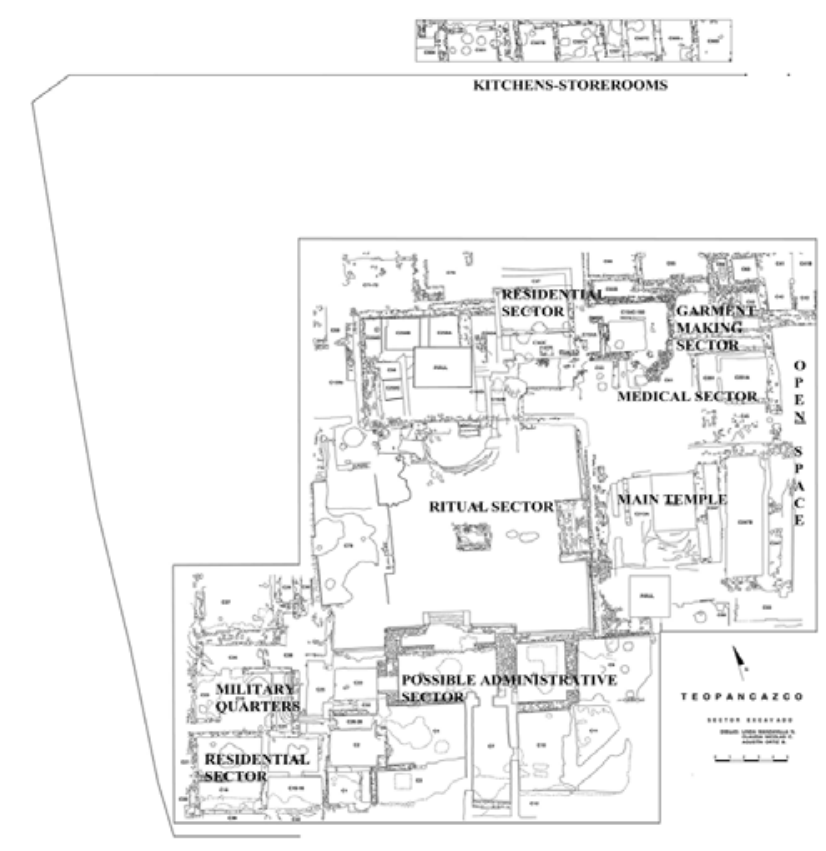

Figure 3: The Teopancazco neighborhood center and its functional sectors
Most craft specialists at Teopancazco came from the corridor of ally sites to Nautla, Veracruz. Their migratory status was identified through strontium and oxygen isotopes, and their diversity was stressed in their genetic haplogroups [5].

The producers of different crafts and the holders of different offices may be identified by: representations in mural paintings or in figurines; by activity markers in their skeletons; by the instruments of their craft or activity associated to their burial. Common people are represented, for example, in cultivation activities, blow-gun bird hunting, butterfly trapping, and recollection of fruits and branches in the "Tlalocan" mural painting in Tepantitla. Porters of goods, divers, fiber workers, net fishermen, painters or garment-makers have individuated by activity markers in their skeletons at Teopancazco [11].

This work describes the whole range of body colors with medical properties found in different contexts in the multiethnic neighborhood center of Teopancazco. Our study suggests that the preparation and confection of body colors (i.e., pigments used for painting one's skin) was one of the specialized activities at Teopancazco. Another specialized activity was the practice of medicine. Both are closely related.

A careful analysis of functional sectors in the Teopancazco compound, and the interdisciplinary perspective implemented by Linda R. Manzanilla, et al [9] and her team provided new information on medical practices in Teotihuacan, the most important city of Classic Mesoamerica. This research states that important activities provided by specialists based in neighborhood centers were medical interventions, child-birth assistance, and the preparation of medical prescriptions.

\section{Methods: Experimental Issues}

\section{Samples and contexts}

The set of materials analyzed were contained in small ceramic vessels that were found in (1) a mortuary context related to burials 105-108, (2) a large mortuary pit where decapitated individuals were interred (AA144), (3) burials 115 and 116, and (4) in rooms C251 A (activity area 154), C162 D (activity area 168), C 262B (activity area 208), C 251 A (activity area 92), C260 (activity area 206), C83 (activity area 170), and C162E (activity area 188). All these samples and its contexts are dated from the Tlamimilolpa and Xolalpan phases (AD 200-550).

\section{Analytical methods}

The analytical protocol is based on the combination of several non-destructive and micro-destructive instrumental techniques, namely, Light Microscopy (LM), Scanning Electron Microscopy-XRay Microanalysis (SEM-EDX), Transmission Electron Microscopy (TEM), UV-vis Spectrophotometry, FTIR Spectroscopy, and Gas Chromatograpy-Mass Spectrometry (GC-MS).

\section{Light Microscopy}

A stereoscopic light microscope Leica GZ6 (X10-X50) was used for selecting the samples to be analyzed and a polarized light microscope Leica DM2500 P (Leica Microsystems. Heidelberg, 
Germany) was used for morphological and petrographic examination of the minerals. Leica Digital FireWire Camera (DFC) with Leica Application Suite (LAS) software has been used for acquiring and processing the digital images. Samples were prepared by softly grinding a few micrograms of the pigmenting materials in a small agate mortar and then extended them on a slide and protected with a thin cover slide. Mounting medium was not used.

\section{Scanning Electron Microscopy-X-Ray Microanalysis}

Chemical composition of the minerals was obtained using a Jeol JSM 6300 scanning electron microscope operating with a Link- Oxford-Isis X-ray microanalysis system. The analytical conditions were: $20 \mathrm{kV}$ accelerating voltage, $2 \times 10^{-9}$ A beam current and $15 \mathrm{~mm}$ as working distance. Samples were carbon coated to eliminate charging effects. Quantitative microanalysis was carried out using the ZAF method for correcting inter elemental effects. The counting time was $100 \mathrm{~s}$ for major and minor elements. The standards used were the following minerals: Albite (Na),MgO(Mg), Al203 (Al), Quartz (Si), GaP (P), FeS2 (S),MAD-10 feldspar (K), Fe (Fe), Mn (Mn), wollastonite (Ca), Ti (Ti), PbF2 (Pb), Zr ( $\mathrm{Zr}), \mathrm{Cr}(\mathrm{Cr}), \mathrm{Ni}(\mathrm{Ni}), \mathrm{V}(\mathrm{V}), \mathrm{Cu}(\mathrm{Cu}), \mathrm{Ag}$ (Ag), $\mathrm{Hg}(\mathrm{HgTe}), \mathrm{Ba}(\mathrm{BaF} 2)$. Element percentages were generated by ZAF software on the Oxford-Link-Isis EDX. Average chemical composition of the samples consisting of several microcrystalline mineral phases corresponds to the mean value obtained from triplicate quantitative measurements from an area of the powdered sample at ca. $100 \mathrm{~mm}^{2}$. In parallel, quantitative spot measurements on the surface of individual grains and aggregates provided the chemical composition of the different mineralogical phases contained in the sample. Precision of measurements is given by the standard deviation. Detection limit for the studied elements was $0.01 \%$. Clay standards were used for checking SEM-EDX measurements.

\section{Transmission Electron Microscopy}

A transmission electron microscope, PhilipsCM10 with Keen view camera and soft imaging system was used operating at 100 $\mathrm{kV}$. Samples from Teopancazco burial were prepared by softly grinding a few micrograms of the samples in an agate mortar and then dispersing them by the help of an ultrasonic bath in dichloroethane. A drop of the dispersion was poured on TEM grids pretreated with a polymer film layer with holes in order to improve the images obtained.

\section{FTIR Spectroscopy}

The IR spectra in the ATR mode of the powdered samples were obtained using a Vertex 70 Fourier-transform infrared spectrometer with a FR-DTGS (fast recovery deuterated triglycine sulfate) temperature-stabilized coated detector and a MKII Golden Gate Attenuated Total Reflectance (ATR) accessory. A total of 32 scans were collected at a resolution of $4 \mathrm{~cm}^{-1}$ and the spectra were processed using the OPUS/ IR software.

\section{UV-Vis Spectrophotometry}

Diffuse reflectance spectra in the UV and visible regions of the samples finely powdered were obtained using a Perkin Elmer
Lambda 1,050 recording double-beam spectrophotometer with a special back-scattering configuration. Reflectance measurements were carried out in the range from 200 to $850 \mathrm{~cm}^{-1}$. The device allows a $1 \mathrm{~nm}$ wavelength resolution and a precision on the reflectance factor equal to $0.1 \%$. In order to perform the reflectance measurements, a few micrograms of sample were homogenized with a drop of nujol oil in a small agate mortar. The paste formed was applied as a thin film on a disk of paper Whatman 42 with the help of a scalpel. Thus, a circular surface ( $5 \mathrm{~mm}$ ) was covered of a homogeneous layer of pigment ready for measuring. A second disk in which pure nujol oil was applied was used as blank for subtracting to the samples and thus suppressing the contribution of the nujol used as binder to the reflectance spectrum.

\section{Gas Chromatography-Mass Spectrometry}

An Agilent 5973N mass spectrometer coupled to an Agilent $6890 \mathrm{~N}$ gas chromatograph (Agilent Instruments, USA) was used for identifying the organic materials present in some of the samples. Agilent Chemstation software (MSD) was used for the integration of peaks and for the mass spectra evaluation. GC separation was achieved in a chemically bonded fused-silica capillary column HP-5-MS (Agilent, USA), (stationary phase 5\% phenyl-95\% methylpolysiloxane, $30 \mathrm{~m}$ x $0.25 \mathrm{~mm}$ i.d., and 0.25 $\mu \mathrm{m}$ film thicknesses). Two methods of derivatization have been applied:

(a) Direct Silylation: Resinous material in samples 7, 10, 11 and 15 was selected mechanically with the help of a scalpel under the optical microscope $(0.1 \mathrm{mg})$ and grinded in an agate mortar. Then, the sample is treated directly with $6 \mu \mathrm{L}$ of TMSI and $3 \mu \mathrm{L}$ of TMCS under $\mathrm{N}_{2}$ atmosphere at $80{ }^{\circ} \mathrm{C}$ for $15 \mathrm{~min}$. The excess of derivatization reagent is eliminated by adding $100 \mu \mathrm{L}$ of water and the derivatives are extracted with $50 \mu \mathrm{L}$ of chloroform. After shaking the mixture by ultrasons for $15 \mathrm{~min}$, a $1.5 \mu \mathrm{L}$ aliquot of the organic phase is injected for $\mathrm{GC}$ analysis. The chromatographic conditions were: temperature initial of the gas chromatograph $100^{\circ} \mathrm{C}$. Oven temperature was programmed with a gradient of $20{ }^{\circ} \mathrm{C} \mathrm{min}^{-1}$ up to $295{ }^{\circ} \mathrm{C}$ held for $12 \mathrm{~min}$. The carrier gas was He with inlet pressure of $99.89 \mathrm{kPa}$ and 1:20 split ratio. The electronic pressure control was set to constant flow mode $\left(1.3 \mu \mathrm{L} \mathrm{min}^{-1}\right)$ with vacuum compensation. Ions were generated by electron ionisation $(70 \mathrm{eV})$ in the ionisation chamber of the mass spectrometer. The mass spectrometer was scanned from $\mathrm{m} / \mathrm{z} 20 \mathrm{e} 800$, with a cycle time of $1 \mathrm{~s}$.

(b) Methanolysise Silylation: for the methanolysis and trimethylsilylation the powdered samples are taken up in $0.5 \mu \mathrm{L}$ of a methanolic $\mathrm{HCl}$ solution prepared by adding acetyl chloride $(100 \mu \mathrm{L})$ to $3.75 \mathrm{~mL}$ of methanol. Methanolysis is conducted at 60 ${ }^{\circ} \mathrm{C}$ for $24 \mathrm{~h}\left(80{ }^{\circ} \mathrm{C}\right.$ for the last $\left.30 \mathrm{~min}\right)$ to facilitate the conversion of monosaccharides into pyranosides (Mejanelle et al., 2002). Then, methanol is removed using a nitrogen stream and the residue is treated as in the previous methodology (direct silylation). The chromatographic conditions were: split mode (1:20 split ratio) for injection of the sample and oven program consisting of 100 ${ }^{\circ} \mathrm{C}$ for $2 \mathrm{~min}$ and then at $6{ }^{\circ} \mathrm{C} \mathrm{min}^{-1}$ up to $300{ }^{\circ} \mathrm{C}$ for $5 \mathrm{~min}$. Gas flow was set to constant mode at $1.3 \mu \mathrm{L} \mathrm{min}^{-1}$. Mass spectrometer conditions were the same as for the direct silylation procedure. 


\section{Results and Discussion}

The body colors identified at Teopancazco to date are mixtures of pigments, organic additive, clays and mica [Tables 1-3]. The purpose of many of the mixtures was to create body pigments which served not only to paint the body, but also to confer hygienic-medicinal properties on the skin.

\section{(a) White body colors prepared with calcite and illite}

To this category we can ascribe, for example, the white color made of calcite and illite, laminar-type white clay (ref. 79057)
[Figure $4 \mathrm{a}-\mathrm{b}$ ]. The chromatic hue of this white pigment could have been procured just as easily by using calcite, but the addition of illite conferred a novel intense luminosity, a similar effect to what obtains by adding mica. This luminous resemblance is due to the close structural similarity between illite and mica, especially muscovite-type mica [12]. However, illite contains a higher proportion of water [12], which confers two added properties on this clay that account for its use in ancient and modern cosmetics alike, ever since early Mesopotamia [13]. These two properties are luminance and moisturizing, which are very fitting for making face masks, which was the probable purpose of the white material in sample 79057.

Table 1: The body colors discovered at Teopancazco: samples and contexts

\begin{tabular}{|c|c|c|}
\hline Sample & Description & Burial Or Ritual Context \\
\hline 75679 & A yellow pigment pellet & Burial 105-108 \\
\hline \multicolumn{3}{|c|}{ Jarosite $\mathrm{KFe} 2(\mathrm{SO4}) 2(\mathrm{OH}) 6$ + Mica (biotite) + Chia oil (Salvia Hispanica L.) } \\
\hline 74498 & A yellow pigment pellet & Burial 105-108 \\
\hline 78165 & A yellow pigment pellet & Burial 105-108 \\
\hline \multicolumn{3}{|c|}{ Jarosite $\mathrm{KFe} 2(\mathrm{SO}) 2(\mathrm{OH}) 6$ + Limonite $(\mathrm{Fe} 2 \mathrm{O3.nH2O})+$ Hematite (Fe203) + Mica (biotite) } \\
\hline 77568 & A yellow pigment pellet & Burial 105-108 \\
\hline \multicolumn{3}{|c|}{ Jarosite $\mathrm{KFe} 2(\mathrm{SO}) 2(\mathrm{OH}) 6$} \\
\hline 76689 & A gray-black coloring material in a miniature plate & Burial 105-108 \\
\hline \multicolumn{3}{|c|}{ Galena (PbS) + Halloysite/Kaolinite (Al2Si2O5 (OH)4) } \\
\hline 76681 & A gray-black coloring material in a miniature bowl & Burial 105-108 \\
\hline 75610 & A gray-black coloring material in a miniature pot & Burial 105-108 \\
\hline 76111 & A gray-black coloring material on the surface of a seal & Burial 105-108 \\
\hline 79058 & A gray-black coloring material in a miniature bowl & Burial 105-108 \\
\hline \multicolumn{3}{|c|}{ Galena (PbS) + Charcoal (C) } \\
\hline 76688 & A gray-black coloring material in a miniature bowl & Burial 105-108 \\
\hline \multicolumn{3}{|c|}{ Galena (PbS) + Charcoal (C) + Mica (biotite) } \\
\hline \multirow[t]{2}{*}{75621} & A black coloring material in a miniature pot & Burial 105-108 \\
\hline & Manganese oxide (MnO) & \\
\hline 76955 & A red coloring material in a miniature plat & Burial 105-108 \\
\hline \multicolumn{3}{|c|}{ Cinnabar (HgS) + Goethite $(\mathrm{FeOOH})+$ Pine-resin fragrance (Pinus montezumae ) } \\
\hline 75511 & A red pigment pellet & Burial 105-108 \\
\hline \multicolumn{3}{|c|}{ Cinnabar (HgS) + Limonite (Fe203.nH20)+ Chia oil (Salvia hispanica L.) } \\
\hline 78200 & A red pigment pellet & Burial 105-108 \\
\hline \multicolumn{3}{|c|}{ Cinnabar (HgS) + Goethite (FeOOH) + Chia oil (Salvia hispanica L.) } \\
\hline 75868 & A red pigment pellet & Burial 105-108 \\
\hline \multicolumn{3}{|c|}{ Goethite $(\mathrm{FeOOH})+$ Pine-resin fragrance (Pinus montezumae $)+$ Mica (biotite) } \\
\hline 75443 & A red pigment pellet & Burial 105-108 \\
\hline 23985 & A red pigment pellet & Burial 105-108 \\
\hline 68056 & A red coloring material in miniature vessel & $\begin{array}{l}\text { Corridor with well-preserved stucco } \\
\text { floor }\end{array}$ \\
\hline \multicolumn{3}{|c|}{ 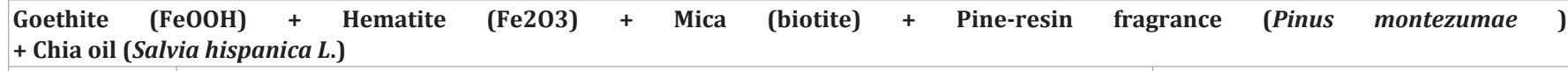 } \\
\hline 76861 & A red pigment pellet & Burial 105-108 \\
\hline \multicolumn{3}{|c|}{ Goethite $(\mathrm{FeOOH})+$ Hematite $(\mathrm{Fe} 203)+$ Pine-resin fragrance (Pinus montezumae $)+$ Mica } \\
\hline 71695 & A red pigment pellet & Burial 105-108 \\
\hline \multicolumn{3}{|c|}{ Cinnabar (HgS) + Calcite CaCO3 + Pine-resin fragrance (Pinus montezumae) + Chia oil (Salvia hispanica L.) } \\
\hline
\end{tabular}




\begin{tabular}{|c|c|c|}
\hline 73144 & A red pigment pellet & Burial 105-108 \\
\hline 76421 & A red pigment pellet & Burial 105-108 \\
\hline 76683 & A red coloring material on seal & Burial 105-108 \\
\hline 76687 & A red coloring material on four-petaled seal & Burial 105-108 \\
\hline 75616 & A red coloring material on seal & Burial 105-108 \\
\hline 76107 & A red coloring material on seal & Burial 105-108 \\
\hline 75608 & A red coloring material on seal & Burial 105-108 \\
\hline 76105 & A red coloring material on seal & Burial 105-108 \\
\hline 75613 & A red coloring material on four-petaled seal & Burial 105-108 \\
\hline 75607 & A red coloring material on seal & Burial 105-108 \\
\hline 76682 B & A red coloring material on seal & Burial 105-108 \\
\hline \multicolumn{3}{|c|}{ Red Earths (Varieties of hydrated iron oxide, goethite-type-FeOOH-) + Organic n.i + Mica (biotite) } \\
\hline $76682 \mathrm{~A}$ & A red coloring material on seal & Burial 105-108 \\
\hline \multicolumn{3}{|c|}{ Cinnabar (HgS) + Hematite (Fe2O3) + Halloysite/Kaolinite (Al2Si2O5 (OH)4) } \\
\hline 79056 & A white coloring material in a miniature vessel & Burial 115 \\
\hline \multicolumn{3}{|c|}{ Diatoms (Bacillaryophyta) } \\
\hline 79057 & A white coloring material in a miniature vessel & Burial 115 \\
\hline \multicolumn{3}{|c|}{ Calcite CaCO3 + Illite-type Clay (K, Na, Ca)2 03.33(Mg, Mn)0.43 (Al, Fe, Ti)2 02.16(Si, Al) 02.4H20 } \\
\hline 79257 & An orange coloring material in a miniature vessel & Burial 116 \\
\hline \multicolumn{3}{|c|}{ Hematite (Fe203) + Ilmenite (FeTiO3) + Quartz (SiO2) } \\
\hline 79256 & A red coloring material in a miniature vessel & Burial 116 \\
\hline \multicolumn{3}{|c|}{ Hematite (Fe2O3) + Halloysite/Kaolinite (Al2Si2O5 (OH)4) } \\
\hline 68899 & A yellow pigment pellet & Pit of the decapitated \\
\hline 66386 & A yellow pigment pellet & Burial 51; Pit of the decapitated \\
\hline \multicolumn{3}{|c|}{ Limonite (Fe203.nH20) + Mica (biotite) + Pine-resin fragrance (Pinus montezumae) } \\
\hline 66523 & A yellow pigment pellet & Pit of the decapitated \\
\hline 72090 & A yellow pigment pellet & Pit with materials \\
\hline 72537 & A yellow pigment pellet & Pit with materials \\
\hline \multicolumn{3}{|c|}{ Jarosite $\mathrm{KFe} 2(\mathrm{SO}) 2(\mathrm{OH}) 6$ + Cinnabar (HgS) + Hematite (Fe2O3) + Mica (biotite) } \\
\hline 70204 & A yellow pigment pellet & Pit of the decapitated \\
\hline \multicolumn{3}{|c|}{ Jarosite $\mathrm{KFe} 2(\mathrm{SO}) 2(\mathrm{OH}) 6$ + Goethite $(\mathrm{FeOOH})+$ Mica (biotite) } \\
\hline 68884 & A red coloring material in a miniature vessel & Burial 67; Pit of the decapitated \\
\hline \multicolumn{3}{|c|}{ Cinnabar (HgS) + Hematite (Fe203) } \\
\hline 67188 & A red coloring material in a miniature vessel & A disposal pit? \\
\hline \multicolumn{3}{|c|}{ Hematite (Fe203) } \\
\hline 79059 & A red coloring material in a miniature jug & A disposal pit? \\
\hline \multicolumn{3}{|c|}{ Hematite (Fe203) + Calcite $\mathrm{CaCO3}$} \\
\hline 66666 & A red coloring material in a miniature vessel & A disposal pit? \\
\hline 65193 & A red coloring material in a miniature vessel & $\begin{array}{l}\text { Square room under garment } \\
\text { Workshop num. } 1\end{array}$ \\
\hline \multicolumn{3}{|c|}{ Hematite (Fe203) + Charcoal (C) + Mica (biotite) } \\
\hline 69064 & A yellow pigment pellet & Rectangular corridor \\
\hline \multicolumn{3}{|c|}{$\begin{array}{l}\text { Jarosite } \mathrm{KFe} 2(\mathrm{SO4}) 2(\mathrm{OH}) 6+\text { Cinnabar }(\mathrm{HgS})+\text { Goethite }(\mathrm{FeOOH})+\text { Mica (biotite) + Pine-resin fragrance } \\
\text { (Pinus montezumae })+ \text { Chia oil (Salvia hispanica L.) }\end{array}$} \\
\hline 65218 & A yellow pigment pellet & Room with access to the main courtyard \\
\hline \multicolumn{3}{|c|}{ Jarosite $\mathrm{KFe}(\mathrm{SO}) 2(\mathrm{OH}) 6$ + Goethite $(\mathrm{FeOOH})+$ Hematite $(\mathrm{Fe} 2 \mathrm{O3})$ + Mica (biotite) } \\
\hline 66155 & A red coloring material in a miniature vessel & Room under C162 B \\
\hline & Hematite (Fe203) + Animal Carbon? Ca5(PO4) & \\
\hline
\end{tabular}


Table 2: Complex formulations identified in the body colors from Teopancazco (mixtures of two or more components)

\section{(1) Yellow colors}

Jarosite KFe2(SO4)2(OH)6 + Mica (biotite) + Chia oil (Salvia Hispanica L.)

Jarosite KFe2(SO4)2(OH)6 + Limonite (Fe2O3.nH2O) + Hematite (Fe2O3) + Mica (biotite)

Jarosite KFe2(SO4)2(OH)6 + Cinnabar $(\mathrm{HgS})+$ Hematite (Fe2O3) + Mica (biotite)

Jarosite $\mathrm{KFe} 2(\mathrm{SO} 4) 2(\mathrm{OH}) 6+$ Goethite $(\mathrm{FeOOH})+$ Mica (biotite)

Jarosite KFe2(SO4)2(OH)6 + Cinnabar $(\mathrm{HgS})+$ Goethite $(\mathrm{FeOOH})+$ Mica (biotite) + Pine-resin fragrance (Pinus montezumae $)+$ Chia oil (Salvia hispanica L.)

Jarosite KFe2(SO4)2(OH)6 + Goethite $(\mathrm{FeOOH})+$ Hematite (Fe2O3) + Mica (biotite)

Limonite (Fe203.nH20) + Mica (biotite) + Pine-resin fragrance (Pinus montezumae)

\section{(2) Gray-black colors}

Galena $(\mathrm{PbS})+$ Halloysite/Kaolinite (Al2Si2O5 (OH)4)

Galena $(\mathrm{PbS})+$ Charcoal $(\mathrm{C})+$ Mica (biotite)

\section{(3) Red and orange colors}

Cinnabar $(\mathrm{HgS})+$ Goethite $(\mathrm{FeOOH})+$ Pine-resin fragrance (Pinus montezumae)

Cinnabar (HgS) + Limonite (Fe203.nH20)+ Chia oil (Salvia hispanica L.)

Cinnabar $(\mathrm{HgS})+$ Goethite $(\mathrm{FeOOH})+$ Chia oil (Salvia hispanica L.)

Cinnabar (HgS) + Calcite CaCO3 + Pine-resin fragrance (Pinus montezumae ) + Chia oil (Salvia hispanica L.)

Cinnabar (HgS) + Hematite (Fe203) + Halloysite/Kaolinite (Al2Si2O5 (OH)4)

Cinnabar (HgS) + Hematite (Fe203)

Hematite (Fe203) + Ilmenite (FeTiO3) + Quartz (SiO2)

Hematite (Fe2O3) + Halloysite/Kaolinite (Al2Si2O5 (OH)4)

Hematite (Fe203) + Charcoal (C) + Mica (biotite)

Hematite (Fe203) + Animal Carbon? Ca5 (P04)30H + Mica (biotite)

Hematite $(\mathrm{Fe} 2 \mathrm{O3})+$ Calcite $\mathrm{CaCO} 3$

Goethite $(\mathrm{FeOOH})+$ Pine-resin fragrance (Pinus montezumae $)+$ Mica (biotite)

Goethite $(\mathrm{FeOOH})+$ Hematite $(\mathrm{Fe} 2 \mathrm{O} 3)+$ Mica (biotite) + Pine-resin fragrance (Pinus montezumae ) + Chia oil (Salvia hispanica L.)

Goethite $(\mathrm{FeOOH})+$ Hematite $(\mathrm{Fe} 2 \mathrm{O3})+$ Pine-resin fragrance (Pinus montezumae $)+$ Mica

Red Earths (Varieties of hydrated iron oxide, goethite-type-FeOOH-) + Organic n.i + Mica (biotite)

\section{(4) White colors}

Calcite CaCO3 + Illite-type Clay (K, Na, Ca)2 03.33(Mg, Mn)0.43 (Al, Fe, Ti)2 02.16(Si, Al) 02.4H20

\section{Table 3. The simple body colors from Teopancazco}

Yellow color: jarosite $\mathrm{KFe} 2(\mathrm{SO} 4) 2(\mathrm{OH}) 6$

Black color: manganese oxide ( $\mathrm{MnO})$

White color: diatoms (Bacillaryophyta)v

Red color: hematite (Fe203)

Illite, however, contributed more than just luminance to this white cosmetic; it conferred hygienic-medicinal properties based on its capacity to absorb skin impurities. This is the reason why illite was used in antiquity to prepare face masks. Illite was also employed in pelotherapy treatments, i.e., the use of natural clay for therapeutic purposes in the form of mud baths, applied on the skin for its purifying and medicinal effect. It is probable, therefore, that these types of clays and cosmetic products with medicinal properties were used in the temazcal or Mesoamerican steam bath, the name deriving from the Aztec word, temazcalli.
In this sense, we should not forget that one of the main hygienicmedicinal purposes of the temazcalli was, precisely, the treatment of skin disorders and diseases [14].

It is worth noting that illite is also a constituent component of the other white body color-diatomaceous earth (ref. 79056) - that was identified and characterized in the burials at Teopancazco [Figure 5a-h]. This earth is made from the fossilized remains of aquatic organisms called diatoms. Diatoms (Bacillaryophyta) are hard-shelled, unicellular algae that the people of Teotihuacan would have obtained from the fossil deposits lying in the sedimentary layers of ancient dried-out lakes in the Basin of Mexico [15]. The siliceous and clayey substrate of the diatomaceous earths can be associated with other minerals, which would explain the vast chromatic variety of these earths that ranges from pure white to black, through yellow-white, rosywhite and gray-white [15]. The Aztecs named this white earth tizatl [16]. 
To conclude, it is important to note that in Ancient Mesoamerica calcite was probably one of the most abundant cosmetic, given the numerous mineral deposits dotting the lands of almost all the cultures that converged on this cultural area, including Teotihuacan. The high covering power of this white coloring material enabled them to create cosmetic films to protect the skin from environmental hazards. Moreover, used as cosmetic calcite was easily smeared on the skin because it was compatible with water, saliva, protein agglutinants, all types of polysaccharides, blood and urine.

\section{(b) The role of diatomaceous earth in Teopancazco white cosmetics}

The use of diatomaceous earths in medicine and cosmetics dates back to Ancient Mesopotamia. It was used because of its antiseptic, antibacterial and fungicide properties, which act upon the skin as a barrier against germs, bacteria and fungi, just as do algae [17]. These and other properties, like the antioxidants and anticoagulants that some species contain, were known and applied for medical use in ancient Near Eastern and North African civilizations [17], and possibly also in the Andean area In this latter region, alginate has been identified by Infrared Spectroscopy as a constituent of the yellow natrojarosite pigments $\left(\mathrm{NaFe}_{3}\left(\mathrm{SO}_{4}\right)_{2}(\mathrm{OH})_{6}\right)$ found at the Pre-Hispanic necropolis of Playa

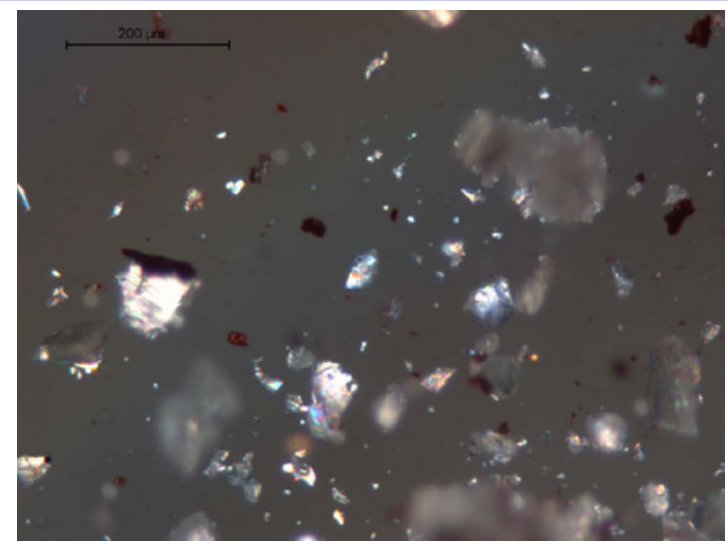

Figure 4a: The white body color elaborated with calcite 79057

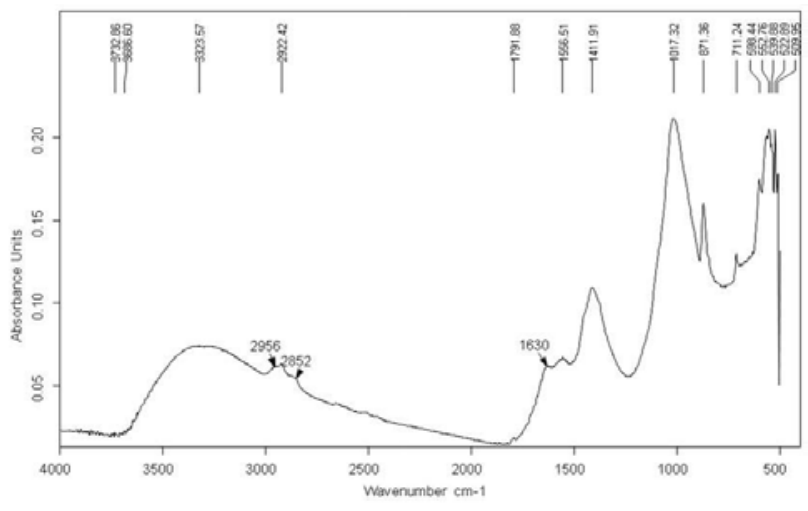

Figure 4b: The white body color elaborated with illite/sample 79057

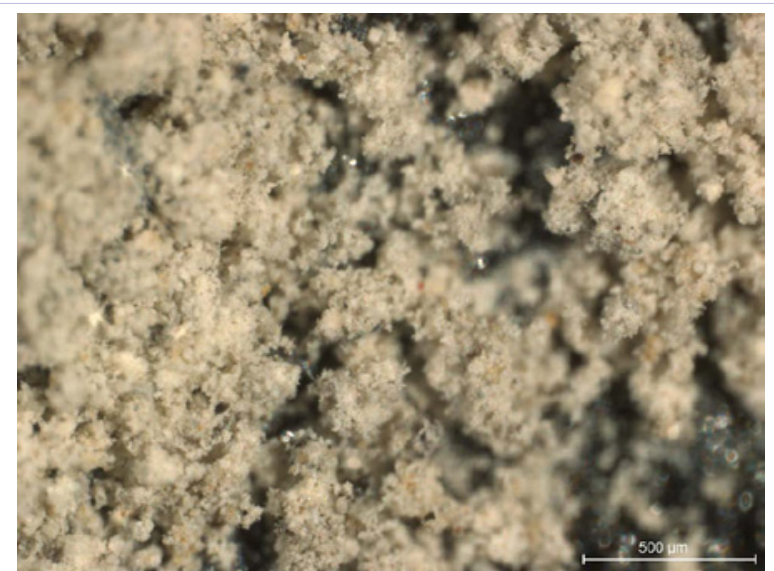

Figure 5a: The white body color prepared with diatomaceous earth/ sample 79056
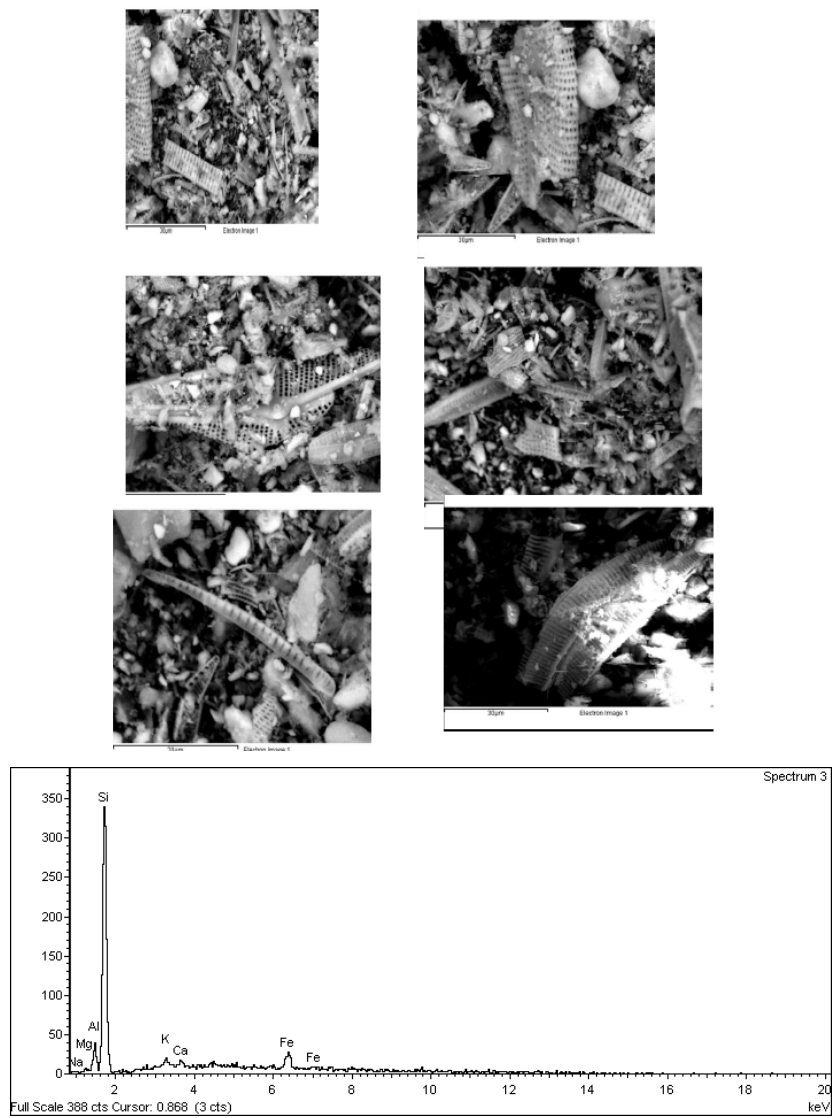

Figure 5b: The white body color prepared with diatomaceous earth/ sample 79056, SEM (5b-g) and EDX (5h)

Miller 7 (on the remote northern coast of Chile; ca. $500 \mathrm{BC}$ to AD 900-1450), which seems to confirm the use of algae in the Andean area as an organic material used to agglutinate pigments that were destined for different purposes, one of which was to treat the skin with its medicinal properties [18].

The medicinal properties of diatomaceous earths are further attested in the prescriptions from the Libellus de Medicinalibus 
Indorum Herbis o Manuscrito de la Cruz Badiano. This manuscript prescribes the use of a white earth with medicinal properties which is not the same white earth known as Iztactlalli, thought to be an earthy salt [19]. To ease a sore throat, for example, the manuscript prescribes an herbal beverage, mixed with honey, pumice and a white earth, which could be a diatomaceous earth [19].

\section{(c) Gray-black mixtures of galena and carbon: the Mesoamerican "khol"}

The gray-black body colors identified in the samples 76681, 75610 [Figure 6a-b], 76111 [Figure 6c-d] and 79058 are made from two components: galena (lead sulfide) and charcoal of vegetable origin. This last coloring material was obtained from burning wood and from the charred remains of animal bones. Because charcoal and bone char were so easy to obtain and to apply on the skin, they were the most frequently used cosmetics. They were also compatible with every medium and presented a wide color range of tonalities and high covering power.

The gray-black tonality yields from the mixture of both materials: the dark gray color of galena blackens by adding charcoal. But this was not the only, nor perhaps the most important, function of charcoal in the formulation. Its most important purpose was to ameliorate the harmful effects of galena on the skin, caused by its main ingredient: lead [20-22].

Similar combinations with identical purposes are found in cosmetics like kohl, a pigment used as eyeliner since remote times in Mesopotamia, Egypt or India, and still in use today in the Near and Middle East [23]. There is an ongoing medical debate regarding the toxicity $v s$. the therapeutic properties of kohl, in so far as it protects the eye from ultraviolet sunrays [24]. There is
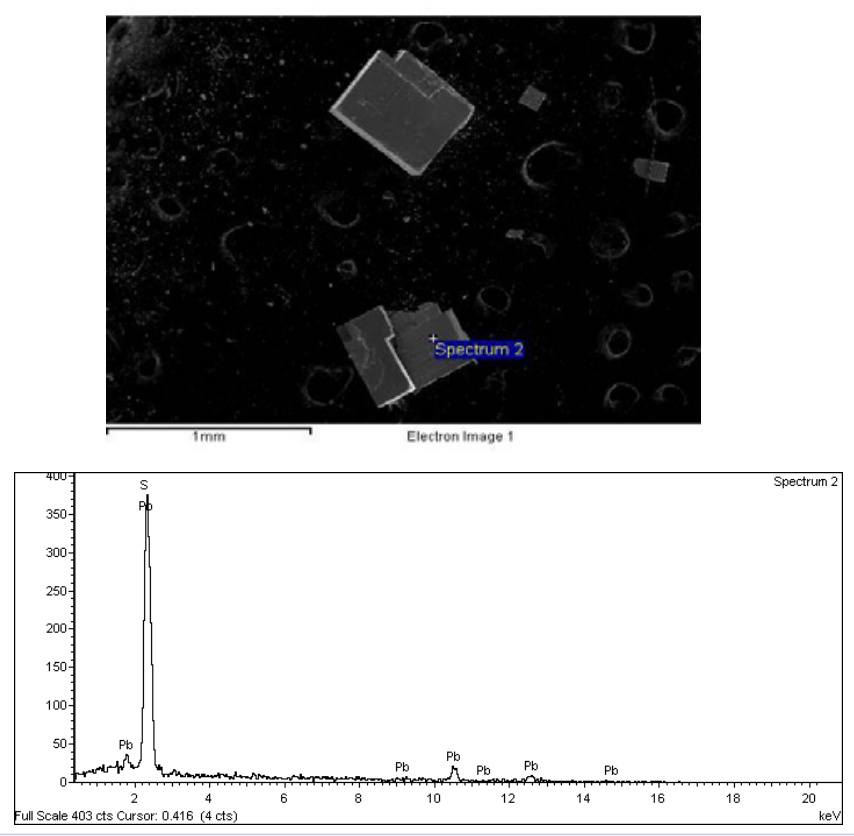

Figure 6a-b: The body colors made with galena and charcoal of vegetable origin consensus, however, on the important role performed by charcoal in the recipe, something already described during the first quarter of the 20th century, after submitting kohl to physicochemical analysis [25]. Already in Ancient Egypt, medical scrolls like the Ebers Papyri, present ophthalmologic prescriptions that combined galena with charcoal and other components, mostly fat, honey, and other minerals, rather than applying galena on its own [26]. The extended use of galena shows that, despite its toxicity, it was deemed to possess important healing properties. However, precisely because of its toxicity, two key variables must have weighed heavily in the formulations that combined galena with other components, such as charcoal or bone char. These key variables are frequency of use [27] and proportionality. Although we lack reports and evidence on the frequency of use in Teopancazco of body colors containing galena [28], samples $76681,75610,76111,79058$ provide evidence of proportionality, i.e., the required proportion of galena in the mixture so as to avoid or lessen its toxic effects. For other hand, and in these same terms, today the well-established toxicity of lead compounds has completely overshadowed their potential benefits for health. New insights about the biochemical interactions between lead (II) ions and cells were obtained by electrochemical analysis of the biological interaction between cells from skin (keratinocytes) and sub-micromolar concentrations of $\mathrm{Pb}^{2+}$ ions in water [29]. A specific oxidative stress response by the cells was observed, consisting essentially of the production of nitrogen monoxide $\left(\mathrm{NO}^{\circ}\right)$ known to play a role in stimulating non-specific immunological defenses in tissues. Then, lead compounds with very low solubility were deliberately manufactured and used in ancient formulations, such as, probably Teopancazco body colors, and of course Ancient Egypt, to prevent and treat eye illnesses by promoting the action of macrophages [30].

The gray-black sample 76688, also combines galena and charcoal, but adds biotite-type mica to the formulation. This type of mica contributes a very special luster to the pigment by imbuing it with the metallic 'shine' of galena [31]. It is the same luster shared by the previously mentioned samples and the same luster that gray sample 76689 also exhibits. This latter sample is particularly interesting because galena is combined with a small proportion of white earth-halloysite/kaolinite-, which for lack of charcoal must have been the component chosen to diminish the toxicity of lead. This occurs because of the internal exchange of ions between these clayey silicates and certain heavy metals, such as mercury or lead, allowing the former to partially absorb the toxicity of the latter [13]. The addition of halloysite / kaolinite to the gray color in sample 76689 served this purpose, enabling it to counter part of the effects of galena on the skin.

\section{(d) The red and yellow body colors: between toxicity and therapeutic properties}

The major part of red body colors from Teopancazco were made with iron pigments. Hematite (ref. 67188, 79059, 66666, $65193,66155,79256)$ and a wide range of earths (ref. 73144, 76421, 76683, 76687, 75616, 76107, 75608, 76105, 75613, $76682 \mathrm{~B}, 75607)$-among which the goethite type was prevalent (ref. 75868, 75443, 23985, 68056, 76861)-were the most 
prominent red iron pigments in our sample base. Jarosite was the first choice for the yellow iron pigments used on the skin (ref. 75679, 74498, 77568, 78165, 66523, 70204, 72090, $72537,69064,65218)$. Only in two instances was limonite, instead of jarosite, the ferric mineral chosen to prepare yellow colors (ref.68899, 66386). There was only one orange pigment and its composition corresponds to a mixture of ilmenite and hematite with the addition of quartz (ref. 79257). This confirms the preeminence of iron minerals to confect warm-gamut body colors at Teopancazco, those ranging from red to yellow, through orange.

These pigments are not contraindicated for skin application. Quite the opposite is true; their grain can form a film of saturated color that protects against external agents, such as wind or sunrays. We also know that when combined with other organic products of vegetable or animal origin, these earth pigments produce medicines that were widely used in Pre-Hispanic Mexico. The main source of reference for this information is the Libellus de Medicinalibus Indorum Herbis or Manuscrito de la Cruz Badiano. In this manuscript we can read, for example, about the prescribed remedy for bad breath or as remedy for intense menstrual bleeding [19].

Similar prescriptions and recipes are found in many cultures of antiquity. Comparative analyses on formulations used in Ancient Mexico suggest that the beneficial effects of red iron pigments were widely known and extensively applied in Eastern and Western medicine, before and after the conquest of America. To cite one example, around the same time that the inhabitants of Teopancazco were using hematite to paint their bodies red without any health hazard to their skin, the inhabitants of Imperial Rome used this same pigment in cosmetics and medicine, where it was known as Terra de Lemnos. Every year the priestesses of the Temple of Diana prepared this red earth at the goddess's sanctuary on the Island of Lemnos, as described by Pliny and Galen in their respective treatises [32]. Both authors refer to the significant use of this red pigment in three different contexts: painting, ritual and medicine. The medicinal use of the pigment included, for instance, the treatment of epilepsy, known as the "sacred disease" ever since it was thus coined in the Corpus Hippocraticum, given the association that was established in Ancient Greece between this malady, the moon and the goddess Diana [33]. The use of Terra de Lemnos in Western medicine extended from the Greek world well into the 19th century. It is still possible to trace the use of this pigment in existing European pharmacies which have managed to preserve ancient drugs, aromas and cosmetics. Many of these pharmaceutical preparations have been subjected to detailed analysis in the last decade.

Finally, cinnabar was used to prepared some red body colors in Teopancazco $(76955,75511,78200,68884,71695,76682$ A), which combined two to five components, especially white laminar-type clays and red pigments, such as hematite or goethite [Figure 7], both amenable to minimizing the harmful effects of mercury $[20,21,28,34,35]$. Was the most important funerary color in Ancient America. The magical-ritual use of cinnabar derives from its resemblance to blood, insofar as blood stood for life and rebirth. The supposed medicinal benefit provided by cinnabar was due its bright red luster. Cinnabar's shiny surfaceowing to its geological origin amid the intense heat of the soil or vents where it is formed-stood for high color-temperature. Following the principle of opposites (hot-cold), applying a red (i.e. hot) dressing on a part of the body affected by cold-temperature disease could counter its harmful effect. In this way, cinnabar was thought to rebalance body temperature and restore health, which accounts for cinnabar's purported medicinal properties [36]. This counterbalancing play of opposites was a principle which informed much of the Hippocratic and Galenic medicine practiced in Europe up to the Modern era. Although any other pigment or colorant applied on the skin to counterbalance a health disorder could provide a similar beneficial effect, cinnabar added a further "preservative" property of medical-pharmaceutical interest: in the right proportion the high toxicity of mercury helped preserve the body by acting as an insect repellant, thus slowing down the decomposition process.

It is interesting to observe the inclusion of mica [37], a foreign raw material strongly controlled by the Teotihuacan ruling elite, in some of the red mixtures, probably to change the optical qualities of these body colors, and contribute to the brightness and luminosity. In this same sense, in some miniatures, aromatic organic substances, such as resins from pines (Pinus montezumae), were also found [Figure 8]. These substances were mixed with the color and mica, which suggests the use of body colors with fragrant properties). In Ancient Mesoamerica, since at least Preclassic times, similar aromatic substances were traded along the commercial routes together with other prized goods such as salt, used for its preservative power, o certain pigments, such as the cinnabar described above. Some of these fragrant products were copal and liquidambar. All these products were in high demand for their indispensable use in funerary rites, one of the most specialized and ubiquitous spheres of society.

\section{Final Remarks}

The physico-chemical study of the colouring materials found in several tombs and burials of Teopancazco indicates that these

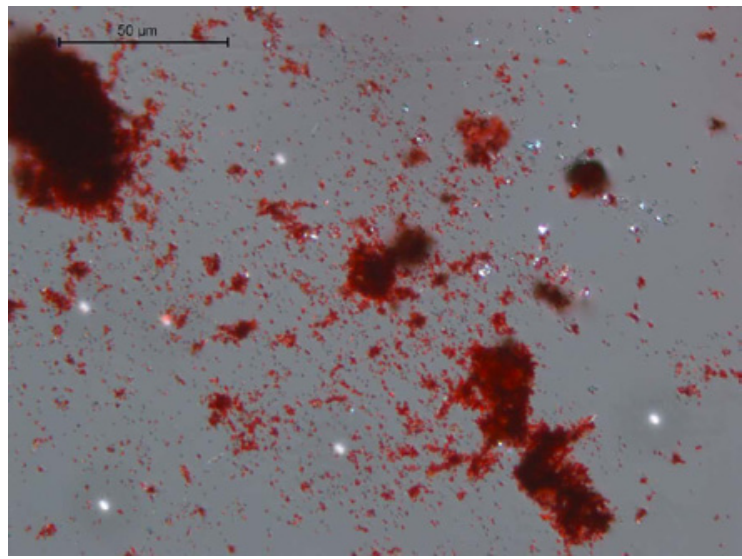

Figure 7: Cinnabar mixed with hematite in sample 68884 
offerings are body colors. The first reason to get to this conclusion has been the identification of pigments that were used mainly as cosmetics in the Antiquity, such us galena and jarosite, both very employed in ancient Middle East and in Egypt. On the other hand, these body colors were not applied as raw materials, but it was prepared in simple or complex formulations that had an aesthetic (to change optical qualities of color, such as brightness, luminosity, texture), hygienic-medicinal (i.e.: antibacterial) and therapeutic purposes (to reduce the harmful effects of some components in contact with the skin). In addition, there is a third reason why we can conclude that these offerings of color found in Teopancazco are cosmetics: the presence of organic substances of the aromatic type in many of them. This combination of color and fragrance was very common in ancient cosmetics [38-41], precisely to fix the scents in the body during extended periods. This line of research, therefore, opens a new and necessary way of study in Teotihuacan, and Mesoamerica in general, due to the close relationship between color, ritual and medicine. In fact, it is probably that this kind of body colors was prepared in Teopancazco by specialists closer to the field of medicine than to the painting.

\section{Acknowledgments}

The Project "Teotihuacan Elite and ruler ship" headed by Linda R. Manzanilla was funded by the following institutions and grants: Consejo Nacional de Ciencia y Tecnología, grants no. 25563H, G36050H, 0082596, 152340; the Institute for Anthropological Research and DGAPA (IN 406199 and IN 404213) of the National Autonomous University of Mexico (UNAM). The permit for this research was granted by the National Institute of Anthropology and History (INAH). On the other hand, this research and the results outlined in the present publication would not have been possible without the support of the Ministry of Economy and Competitiveness (Spain), through the funding of coordinated research programmes, reference numbers ARTE Y ARQUITECTURA MAYA. NUEVAS TECNOLOGIAS PARA SU ESTUDIO Y CONSERVACION (BIA2014-53887-C2-2-P).

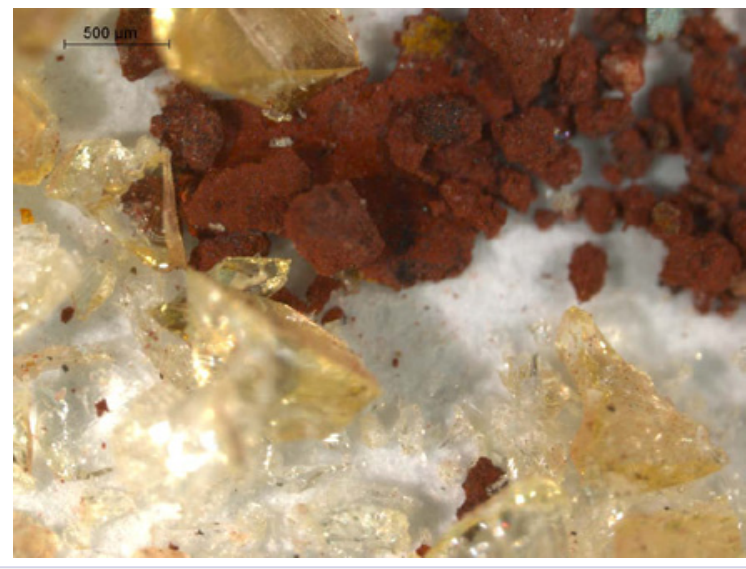

Figure 8: Hematite mixed with the gum from Pinus montezumae

\section{References}

1. Millon R. Urbanization at Teotihuacan. Mexico I, 1. The Teotihuacan Map, Part One: Text, University of Texas Press, Austin, 1973.

2. Manzanilla Linda R. "Chapter 5. Teotihuacan: Urban Archetype, Cosmic Model". In Emergence and Change in Early Urban Societies, ed. L.R. Manzanilla. New York: Plenum Press. 1997;109-132.

3. Manzanilla Linda R. "The iconography of power in Teotihuacan". In Symbols of Power in Mesoamerica, ed. G. Olivier, 111-131. Mexico: Institute of Historical Research (Mesoamerican Cultures Series 5) and Institute of Anthropological Research, National Autonomous University of Mexico. 2008.

4. Manzanilla, Linda R. 2012 "Corporate life in apartment and barrio compounds at Teotihuacan, Central Mexico: craft specialization, hierarchy and ethnicity". In Domestic Life in Prehispanic Capitals. A Study of Specialization, Hierarchy and Ethnicity, eds. L.R. Manzanilla and $\mathrm{Cl}$. Chapdelaine, 21-42. Memoirs of the Museum of Anthropology 46, Studies in Latin American Ethnohistory and Archaeology VII. Ann Arbor: University of Michigan.

5. Manzanilla, Linda R. "Cooperation and tensions in multiethnic corporate societies using Teotihuacan, Central Mexico, as a case study". Proceedings of the National Academy of Sciences. 2015;112(30):92109215.

6. Froese Tom, Carlos Gershenson, Linda R. Manzanilla. Can Government be Self-Organized? A Mathematical Model of the Collective Social Organization of Ancient Teotihuacan, Central Mexico. PLoS One. 2014;9(10):e109966. doi: 10.1371/journal.pone.0109966.

7. Spence, Michael W."Comparative Analysis of Ethnic Enclaves". In Arqueología mesoamericana. Homenaje a William T. Sanders I, eds. A.M. Mastache, J.R. Parsons, R.S. Santley, and M.C. Serra Puche.1996;333-353. México: Instituto Nacional de Antropología e Historia-Arqueología Mexicana.

8. Ortega, Verónica, The Oaxacan presence in Teotihuacán during the Classic, PhD Dissertation in Mesoamerican Studies. Faculty of Philosophy and Letters, National Autonomous University of Mexico, Mexico City, 2014.

9. Manzanilla, Linda R. (ed.) Archaeometric studies of the center of Teopancazco neighborhood in Teotihuacan. Mexico: Coordination of Humanities / Coordination of Scientific Research of the National Autonomous University of Mexico, 2012.

10. Manzanilla, Linda R. "Introduction. Teopancazco, a center of multiethnic neighborhood of Teotihuacan. "In Archaeometric studies of the Teopancazco neighborhood in Teotihuacan, ed. L.R. Manzanilla, 17-66. Mexico: Coordination of Humanities-Coordination of Scientific Research, National Autonomous University of Mexico. 2012.

11. Manzanilla, Linda R. (ed.) Multiethnicity and Migration at Teopancazco. Investigations of a Teotihuacan Neighborhood Center. University Press of Florida, Gainesville, in press.

12 Besoain E. Mineralogy of soil clays. San José de Costa Rica: InterAmerican Institute for Cooperation on Agriculture. 1985.

13. Rytwo Giora. Clay Minerals as an Ancient Nanotechnology: Historical Uses of Clay Organic Interactions, and Future Possible Perspectives. MACLA. 2008;9:15-17.

14. Franch Alcina, Andrés Ciudad Ruíz, Josefina Iglesias. The "temazcal" in Mesoamerica: evolution, form and function. Spanish Journal of American Anthropology. 1980;10:93-132. 
15. Martínez García, Cristina José Luís Ruvalcaba Sil, Linda R. Manzanilla Naim and Francisco Riquelme 2012 "Teopancazco and his painting. Application of analytical techniques PIXE, MEB-EDX, DRX, FTIR and Raman “. In Archaeometric studies of the Teopancazco neighborhood in Teotihuacan, ed. L.R. Manzanilla, 165-210. Mexico: Coordination of Humanities-Coordination of Scientific Research, National Autonomous University of Mexico.

16.Dupey García Élodie. The Materiality of Color in the Body Ornamentation of Aztec Gods. Res. Anthropology and Aesthetics 2015;65/66:70-86.

17. Kumar Vinay, Pren Saran Tirumalai, Abha Singh, A.K. Bhatnagar, J.N Shrivastava. Natural Compounds from Algae and Spirulina platensis \& its Antimicrobial Activity. Indo Global Journal of Pharmaceutical Sciences. 2013;3(3):212-223.

18.Sepúlveda, Marcela, Hélène Rousselière, Elsa Van Elslande, José Cárcamo, and Philippe Walter 2011 Characterization of Yellow Blocks from the Miller 7 Beach Site (North Coast of Chile). In Cultural heritage: management, art, archeology and the exact sciences, eds. Cristina Vázquez, Óscar Martín Palacios, and Nicolás Ciarlo pp. 263270. Buenos Aires: CNEA.

19.De la Cruz, M. Libellus of Medicinalibus Indorum Herbis. Mexico: Fondo de Cultura Económica-Mexican Social Security Institute. 1991.

20. Doménech-Carbó María Teresa, María Luisa Vázquez de ÁgredosPascual, Laura Osete-Cortina, Antonio Doménech-Carbó, Núria GuaschFerré, Linda R. Manzanilla, et al. "Characterization of Prehispanic cosmetics found in a burial of the ancient city of Teotihuacan (Mexico)". Journal of Archaeological Science. 2012;39:1043-1062.

21.Vázquez-de-Ágredos-Pascual M.L., L. R. Manzanilla-Naim, C. VidalLorenzo. "Ancient aromatic essences and funeral cosmetics of the multiethnic neighborhood of Teopancazco (Teotihuacan, Mexico)". In Archaeometric studies of the Teopancazco neighborhood in Teotihuacan, ed. L.R. Manzanilla. 2012;211-232. Mexico: Coordination of Humanities-Coordination of Scientific Research, National Autonomous University of Mexico.

22.Fussler Bagur, E. Rituals and lead poisoning in adults (Unpublished Ph.D). Paris: University of Paris 6. 2011.

23. Hardy Andrew D., Alexander J. Farrant, Gavyn Rollinson, Peter Barss and Ragini Vaishnav. A study of the chemical composition of traditional eye cosmetics ("kohls") used in Qatar and Yemen. Journal of Cosmetic Science. 2008;59: 399-418.

24. Ullah Habib P, Zafar A Mahmood, Mohammad Sualeh, S.M Zoha. Studies on the chemical composition of kohl stone by X-ray diffractometer. Pak J Pharm Sci. 2010;23(1):48-52.

25. Lucas Alfred. Cosmetics, Perfumes and Incense in Ancient Egypt. The Journal of Egyptian Archaeology. 1930;16 (1/2):41-53.
26. Bardinet T. The medical papyrus of Pharaonic Egypt. Paris: Fayard, 1995

27. From Caluwé, Jean-Pierre. Saturnine poisoning caused by the prolonged use of kohl, an underestimated cause in Francophone countries. French journal d'ophtalmologie. 2009;32(7):459-463.

28. Natahi, S., Characterization of pigments and measures of health risks related to their use at Teopancazco. Unpublished M.A. thesis, University Paris I - Pantheon Sorbonne (UFR03 History of Art and Archeology), Paris, 2013.

29. Tapsoda I, S. Arbault, Ph Walter, C Amatore. Finding out Egyptian Gods' secret using analytical chemistry: biomedical properties of Egyptian black makeup revealed by amperometry at single cells. Anal Chem. 2010;82(2):457-60. doi: 10.1021/ac902348g.

30.Vázquez de Ágredos Pascual M.L., M.C. Gamberini, Ph Walter. "Perfumes and Cosmetics in Antiquity". In SAS Encyclopedia of Archaeological Sciences, ed. S. López Varela and L. Barba, in press.

31.Zorzin, Roberto.Conocer los minerales. Susaeta, Madrid. 2002.

32. Photos-Jones, Effie, and Allan J.Hall. Lemnian Earth and the earth's of the Aegean an archaeological guide to medicines, pigments and washing powders. Potingair Press, Glasgow. 2011.

33. Lanata G. Magical Medicine and Popular Religion in Greece. Rome: Edizioni dell'Ateneo, 2007.

34.Liu Jie, Jing-Zheng Shi, Li-Mei Yu, Robert A. Goyer and Michael P. Waalkes. Mercury in traditional medicines: Is cinnabar toxicologically similar to common mercurial? Exp Biol Med (Maywood). 2008;233(7):810-7. doi: 10.3181/0712-MR-336.

35. Rasmussen Kaare Lund, Jesper Lie Boldsen, Hans Krongaard Kristensen, Lilian Skytte, Katrine Lykke Hansen, Louise Molholm, et al. Mercury levels in Danish Medieval human bones. Journal of Archaeological Science. 2008;35: 2295-2306.

36. López Austin Alfredo. Human body and ideology, the conceptions of the ancient Nahua. Mexico: National Autonomous University of Mexico, Institute of Anthropological Research 2012.

37. Manzanilla, Linda R., Xim Bokhimi, Dolores Tenorio, Melania Jiménez, Edgar Rosales, Cira Martínez and Marcus Winter."Origin of Teotihuacan mica: control of foreign sumptuary resources by ruling elites". Anales de Antropología, in press. 2016.

38. Bourliascos A. Scents of Eternity: Methods of Identification of Ancient Perfumes. Paris: Ecole du Louvre. 2004.

39. Giannelli, L. Cosmeci ancient Mediterranean. Montespertoli: M.I.R Editions 2000.

40.Giordano, C, Angelandrea C. Perfumes, unguents and hairstyles in Pompeii. Rome: Bardi Editore, 2007.

41. Maderna, E. sacred aromas. Fragrances profane. Sansepolcro Aboca Edizioni 2009. 